\title{
STATE AND CHURCH IN BYZANTIUM DURING THE CIVIL WAR OF 1321-1328: THE EMPEROR ANDRONIKOS II PALAIOLOGOS AND THE PATRIARCHS GERASIMOS I AND ESAIAS
}

\author{
Pavel I. Lysikov \\ Volgograd State University, Volgograd, Russian Federation
}

\begin{abstract}
The goal of the present research work is to determine the role of church in political events during the war between Andronikos II and Andronikos III Palaiologoi (1321-1328) in the Byzantine empire. Its urgency is defined by incomplete explanation of this aspect in Russian and foreign historiography. The first part of the article is devoted to the study of relations between the state and the church during the Andronikos II Palaiologos' earlier rule (1282-1320). The author concludes that under the church troubles patriarchs sought to rely on the ruling emperor but happened to have no support. As far as state-church relations during the civil war are concerned, they are studied in the second part of the research work. The author puts an emphasis on the patriarchs Gerasimos I (1320-1321) and Esaias' (1323-1334) political position and clears up the degree of their participation in the conflict between the emperors. He finds out that the church role in political events at that time was high enough. The crisis of power led to a change in relations between patriarchs and Andronikos II; in other words, during the civil war period they did not support him and came down on the side of his grandson. At the same time the synod remained loyal to the ruling emperor.
\end{abstract}

Key words: Byzantine empire, civil war of 1321-1328, Andronikos II Palaiologos, Andronikos III Palaiologos, patriarch Gerasimos I, patriarch Esaias, synod.

\section{ГОСУДАРСТВО И ЦЕРКОВЬ В ВИЗАНТИИ В ПЕРИОД ГРАЖДАНСКОЙ ВОЙНЫ 1321-1328 гГ.: ИМПЕРАТОР АНДРОНИК ІІ ПАЛЕОЛОГ И ПАТРИАРХИ ГЕРАСИМ І И ИСАЙЯ}

\author{
Павел Иванович Лысиков \\ Волгоградский государственный университет, г. Волгоград, Российская Федерация
}

\begin{abstract}
Аннотация. Задача исследования заключается в определении роли церкви в политических событиях в империи в период войны между двумя Андрониками 1321-1328 годов. Его актуальность определяется недостаточной освещенностью этого аспекта в отечественной и зарубежной историографии. Первая часть статьи посвящена изучению отношений государства и церкви в годы правления Андроника II Палеолога, предшествовавшие гражданской войне (1282-1320). Делается вывод о том, что в условиях церковных смут 6 патриархи стремились опереться на правящую власть, но зачастую лишались ее поддержки. Во второй ㄱ. части исследуются государственно-церковные отношения непосредственно в годы гражданской войны. Выясняется, что роль церкви в политических событиях этого периода была достаточно высокой. Кризис власти привел к перемене в отношениях между патриархами и Андроником II: во время гражданской войны они выступали на стороне его внука. В то же время синод сохранил лояльность по отношению к правящему императору.

Ключевые слова: Византийская империя, гражданская война 1321-1328, Андроник II Палеолог, Андроник III Палеолог, патриарх Герасим I, патриарх Исайя, синод.
\end{abstract}


Политические события византийской истории в период борьбы за трон между императорами Андроником II и Андроником III Палеологами достаточно подробно освещены в ряде обобщающих и специальных исследований [11, с. 94-102; 12, p. 85-91; 16, S. 752; 26, p. 284-299; 34, p. 151-162; 35, p. 17-28; 38, p. 29-83]. Так или иначе, вопрос выяснения степени вовлеченности клира в политические события эпохи гражданской войны, сопряженный с необходимостью изучения отношений государства и церкви в годы усобицы, зачастую обходился стороной или освещался в недостаточной степени ${ }^{1}$. Таким образом, задача данного изыскания заключается в определении роли церкви в политических событиях в империи в период войны между двумя Андрониками 1321-1328 годов.

\section{1. Андроник II и византийская церковь в 1282-1320 годы}

Прежде чем обратиться к предмету нашего исследования, следует рассмотреть традицию отношений Андроника II и церкви в период, предшествовавший гражданской войне.

За время правления Андроника II Палеолога, которое в общей сложности длилось сорок шесть лет (1282-1328), на патриаршем престоле сменилось девять патриархов. Частая сменяемость владык была обусловлена сложной ситуацией в византийской церкви, лишенной внутреннего единства на рубеже XIII-XIV веков. Отметим, что Андроник получил в наследство от отца, Михаила VIII (1259-1282), империю, в которой уже обозначились черты не только экономического, политического, но и церковного кризиса. Продолжался арсенитский раскол, который фактически будет определять дальнейшую церковную политику императора и патриархов в первые тридцать лет правления Андроника. Арсениты являлись последователями патриарха Арсения Авториана (1255-1260, 1261-1265), который в 1262 г. $^{2}$ отлучил императора Михаила от церкви за ослепление последнего наследника престола из династии Ласкарей Иоанна IV и окончательную узурпацию власти. В ходе противостояния императора и патриарха Арсений, не уступивший давлению Михаила, желавшего снятия отлучения, был низложен синодом по указанию василевса [7, с. $88-89$; 9, с. 49 слл.; 13, S. $194 ; 39$, р. 17]. Движение арсенитов, начавшееся еще в годы жизни низложенного патриарха, являлось мощным фактором, определявшим отсутствие единства в церкви на протяжении почти пятидесяти лет. Антипалеологовская направленность арсенитской схизмы обеспечивала ей ярко выраженный политический фон. Арсениты противостояли как императору, так и патриарху и церковной иерархии в целом. Наибольшее влияние они приобрели в Малой Азии, где были сильны проласкаридские и, следовательно, антипалеологовские настроения [7, c. $90 ; 9$, c. $149,152-153 ; 26$, p. 20].

В 70-80-х гг. XIII в. арсениты являлись противниками Лионской унии церквей (1274). Уния представляла собой второй камень преткновения государственно-церковных отношений в правление двух первых Палеологов. Заключенная вследствие политической, а не церковной необходимости, с целью обезопасить империю от военно-политических притязаний Запада [9, с. 162 слл.; 26, р. 12], она вызвала колоссальный резонанс в обществе и церкви и шквал критики со стороны ее противников ${ }^{3}$, в отношении которых последовали ответные репрессии императора. Уния внесла еще большее расстройство в дела церкви [9, с. 167 слл., 180].

Со сменой власти униатский патриарх Иоанн ХІ Векк (1275-1282) поспешил отречься от престола (1282), а уния, которая оказалась обреченной уже в последние годы правления Михаила [26, p. 13; 36, S. 400], вскоре была уничтожена. Началась борьба с униатами, провозглашенная патриархом Иосифом I (1268-1275, 1282-1283), которому вернули патриарший престол. Некогда Иосиф был лишен патриаршества за свое неприятие унии, что сблизило его и его сторонников с умеренной фракцией в арсенитском течении [9, с. 169 слл.]. Против нового патриарха выступили зилоты, представители радикальной арсенитской фракции, объявив его хиротонию незаконной (ведь первое патриаршество Иосифа пришлось на время жизни патриарха Арсения, смещенного, по мнению арсенитов, незаконно). Таким образом, повторилась ситуация, имевшая место в правление Михаила VIII и состоявшая в борьбе радикальных арсенитов с иосифитами. Отметим, что даже после скорой смерти 
патриарха стороны не примирились, стремясь выдвинуть на патриарший трон своего ставленника [26, p. 34].

В период патриаршества Григория II Кипрского (1283-1289), которого Андроник назначил патриархом во многом по причине того, что тот не был связан ни с одной из конфликтовавших партий, униаты во главе с бывшим патриархом Векком были окончательно разгромлены на соборе 1285 года [9, с. 275 слл.; 13, S. 203]. За год до того Андронику на соборе в Адрамиттии удалось на некоторое время примирить ревнителей и иосифитов [26, p. 34-35]. Впрочем, раскол продолжался, и на этот раз его жертвой стал новый патриарх. В это время даже среди григоритов (сторонников Григория в его борьбе с униатами) не было единства, и те выступили против патриарха в ответ на публикацию его главного антиуниатского сочинения То́ $\mu$ s, каноничность которого оказалась под сомнением [5, с. 337; 9, c. 294 слл.]. В обмен на то, чтобы его признали православным, Григорий на синоде 1289 г. отрекся от престола [9, с. 318-322]. Некоторые исследователи склонны видеть в смещении Григория руку арсенитов, ради мира с которыми император и поспособствовал отставке патриарха [7, с. 92-93; 9, с. 322-324; 39, p. 17].

Назначая следующего патриарха, Андроник II, вероятно, стремился угодить своим выбором арсенитам [10, с. 528; 39, p. 17-18]. Рукоположенный патриархом простой монахаскет Афанасий (Афанасий I, 1289-1293, 13031309), однако же, проводил крутую политику жестких мер как против раскольников, так и против столичного духовенства. Главным образом новый патриарх боролся с абсентеизмом архиереев, которые, находясь вне своих епископств в столице, принимали самое активное участие в политических интригах, формировали противоборствующие партии и вносили смуту во внутреннюю деятельность константинопольского патриархата [9, с. 337-340; 26, p. 36]. Последние, впрочем, снова взяли верх над патриархом, склонив его к отречению. Стремясь уладить церковные раздоры, проводя жесткую реформу духовенства, Афанасий в итоге навлек на себя негодование столичного клира. Андроник II, разочаровавшись в патриархе, который не смог погасить раскол, не препятствовал его отставке (1293), к чему, вполне вероятно, приложили руку и арсениты [9, c. 340-342; 22, p. 13-14; 39, p. 17-18].

Возведение на патриарший престол монаха Космы (Иоанн ХII Созопольский, 12941302) было прямо связано со стремлением императора наконец уладить отношения с арсенитами [9, с. 342-343]. Византийский историк Георгий Пахимер в своем труде отмечает под 1294 г., что «с этого времени василевс снова принялся за арсенитов, надеясь на то, что они заключили бы мир вследствие миролюбия (= мира) патриарха по отношению ко

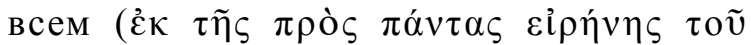
$\pi \alpha \tau \rho \operatorname{\alpha ó} \rho \chi 0 v)$ и умонастроениям, берущим верх над всякой ссорой и любым раздором» [21, p. 233]. Патриарх, впрочем, не стеснялся прямо указывать императору на недостатки его политических и социально-экономических мероприятий и активно вторгался в сферы деятельности, выходящие за рамки его полномочий. В свою очередь владыка сам подвергся критике со стороны епископов, в частности за определенный авторитаризм в управлении церковью, и это в конечном итоге привело к его отречению $\left(1302^{4}\right)$ [9, с. 361 слл.; 22, р. 15]. Андроник вновь не встал на защиту патриарха, на что были свои причины: помимо того что Иоанн открыто критиковал политику Андроника, он оказался не в силах справиться с возложенной на него задачей преодоления схизмы [7, с. 91-92].

Император предпринял новую попытку примирить арсенитов; на этот раз он возобновил переговоры с ними, допуская возможность избрания нового патриарха из среды ревнителей. Впрочем, переговоры не завершились успехом. На патриарший трон был возвращен Афанасий (1303) [9, с. 377 слл.], который, не сделавшись мягче за прошедшие десять лет, снова обратился к политике борьбы с обмирщением духовенства и абсентеизмом епископов [22, p. 16]. Он даже вменял в обязанность императору заботу о византийской церкви и оказывал на него достаточно сильное влияние. Лишь с помощью василевса, по мнению Афанасия, можно было бороться как с засильем епископов в столице, так и с раскольниками [1, с. 54-55]. Последние, к слову, в 1305 г. поучаствовали в заговоре некоего Иоанна Дримия, выдавшего себя за представителя низложенной династии Ласкарей. Заговор был 


\section{ВИЗАНТИЙСКАЯ ПРАВЯЩАЯ ЭЛИТА ПРИ ПАЛЕОЛОГАХ}

тем опаснее, что он пришелся на начало каталонского мятежа и его организаторы пытались связаться с каталонцами; планы заговорщиков, впрочем, были раскрыты, а Дримий схвачен и брошен в тюрьму [2, с. 55-56; 9, с. 416 слл.; 26, p. 197-198].

В конечном итоге Афанасию пришлось столкнуться с той же проблемой, которая послужила причиной и его первого отречения: столичный клир, недовольный реформаторской деятельностью патриарха, оказывал на него и на императора постоянное давление, стремясь сместить неугодного владыку. Мир с арсенитами так и не был установлен; более того, Афанасий оказался препятствием на этом пути [9, c. $433-434 ; 15$, p. 87-89; 22, p. $17 ; 39$, p. 18]. Чрезмерное влияние, которое оказывал на императора патриарх, подверглось порицанию со стороны его противников ${ }^{5}$, и Афанасий, не встречая поддержки слабохарактерного Андроника, вынужден был покинуть свой пост в 1309 году ${ }^{6}[15$, p. $87 ; 39$, p. 18].

Спустя год после отречения Афанасия новому патриарху Нифонту I (1310-1314) наконец удалось прекратить схизму через заключение церковного мира с раскольниками на условиях, выдвинутых последними [15, p. 89; 26 , p. $89-90$; 29 , p. $2-3$, no. 2002 ; 33 , p. $261-$ 262]. Преодоление схизмы, больного вопроса для Андроника, и восстановление мира в церкви совпало с уходом каталонцев из Византии, и император смог употребить все усилия для восстановления подорванного внутренними и внешними неурядицами экономического положения государства. Отметим, что после Афанасия Андроник, очевидно, опасался новых смут и потому тщательно выбирал кандидатов на патриарший престол. Это, на наш взгляд, является причиной более или менее продолжительных пауз между назначением всех последующих патриархов. Этот факт также обусловил специфику их выбора: практически все они, за исключением Иоанна XIII Глики (1315-1319), - который, впрочем, страдал от неизлечимой болезни [33, p. 289] и, следовательно, не мог в полной мере осуществлять свои функции, - согласно нашим источникам, не отличались особенным умом. «Ведь ради того, - пишет византийский историк Никифор Григора ${ }^{7},-$ василевсы и выбирают на такие должности таких людей, чтобы те с го- товностью подчинялись приказам, точно рабы, и никогда не замышляли ничего супротив» [33, p. 292].

Заключим, что в условиях церковных неурядиц патриархи остро нуждались в поддержке со стороны императора в процессе преодоления смут и борьбы со своими противниками из высшего клира. Однако ввиду отсутствия у василевса твердой линии поведения в отношении церкви владыки зачастую лишались содействия с его стороны, что имело своим итогом частую смену патриархов и дальнейшую дестабилизацию отношений внутри церкви.

\section{2. Андроник II и византийская церковь} в годы гражданской войны с внуком

(1321-1328)

Вспыхнувшая 20 апреля 1321 г. гражданская война между Андроником II и его внуком и соправителем Андроником III ввергла страну в очередную - на этот раз политическую - смуту. Византийская церковь и главным образом константинопольские патриархи также приняли участие в этих событиях.

После отставки Иоанна Глики новым патриархом был назначен игумен Манганского монастыря Герасим (Герасим I, рукоположение состоялось 22 марта 1320 г. [3, с. 282]). Патриаршество Герасима длилось всего год, что было связано с его преклонным возрастом, и он стал вторым патриархом за период правления Андроника II (после Иосифа, также умершего на своем посту), избежавшим отречения. От его патриаршества не сохранилось ни одного оригинального акта, лишь упоминания в тех или иных источниках [29, p. 74-75, nos. 2100-2104], но, тем не менее, именно оно оказалось отмечено началом гражданской войны, крупнейшего события в истории Византии первой трети XIV века. Герасим, как и многие из его предшественников, не избежал участия в политических интригах.

Оба историка гражданской войны - Никифор Григора и Иоанн Кантакузин ${ }^{8}$ - достаточно критично отзываются об умственных способностях нового патриарха. Григора более резок и субъективен в оценке Герасима, что, очевидно, связано со спецификой отношения придворного ученого и философа к по- 
луграмотному монашествующему духовен-

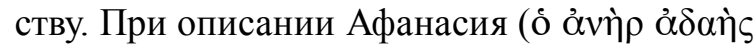

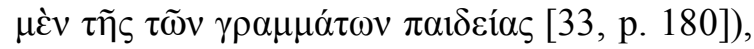

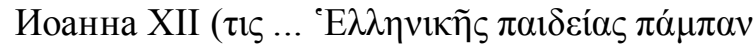

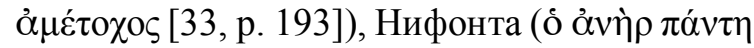

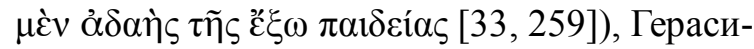

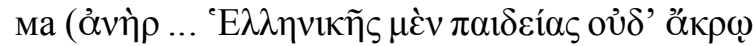

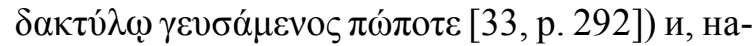

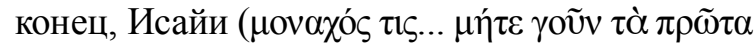

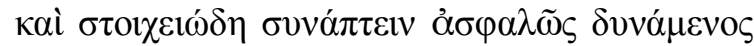
$\gamma \rho \alpha ́ \mu \mu \alpha \tau \alpha[33$, p. 360]) историк в первую очередь отмечает отсутствие должного уровня образованности у всех перечисленных патриархов из монашеской среды. Напротив, Григора выделяет Иоанна XIII Глику, редкого патриарха из мирян [8, с. 80 и прим. 2], сообщая, что «это был человек, в высшей степени ученый и более чем кто-либо сопричастный той исклю-

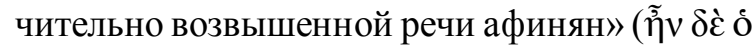

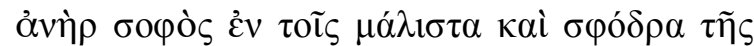

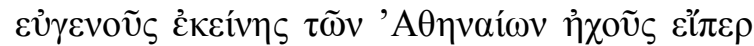

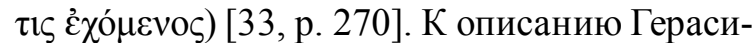
ма Кантакузин добавляет, что тот «достиг вершины монашеской жизни, однако в государственных и общественных делах был совер-

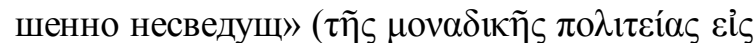

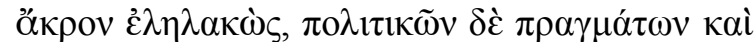

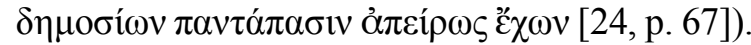
Резко негативный отзыв о познаниях церковного владыки в мирских делах, на наш взгляд, лишен основательности и, скорее всего, вызван стремлением автора раскритиковать участие Герасима в суде над Андроником III, устроенном 5 апреля 1321 г. его дедом Андроником II. В ходе суда, как известно из источников, произошло примирение между двумя императорами, и гражданская война была на некоторое время отсрочена [24, p. 67 ff.; 33, p. 312-313] ${ }^{9}$.

Привлечение к суду над внуком церковных иерархов во главе с патриархом свидетельствует о стремлении старого императора в условиях назревающего политического кризиса заручиться поддержкой церкви. Отметим, что мир в Регии (1321) был заключен через посредничество митрополита Филадельфийского Феолипта [33, p. 320-321], а мир в Эпиватах (1322) - посредством прота Свя-

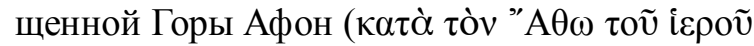

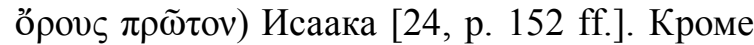
того, сохранились три письма Андроника II, в которых он просит служителей Афона (прота Исаака) [30, p. 309, 310-311], монаха монастыря Ватопеди Никодима [31, p. 312-313] и игумена Ватопеда Нифонта [32, p. 314-315]), молиться во благо государства и за его примирение с внуком. Наконец, следующим после Герасима патриархом был выбран монах с Афона Исайя. Впрочем, не все афонские монастыри, которым старый император оказывал покровительство со времени своего воцарения, его поддержали; к примеру, среди сторонников молодого василевса Кантакузин отмечает игумена монастыря Лавры на Афоне Герасима [14, p. 190; 24, p. 149]. Андроник III, как и его дед, также стремился стяжать симпатии духовенства, осознавая важность поддержки церкви в смутные годы внутренней усобицы. Так, наряду с Герасимом Кантаку-

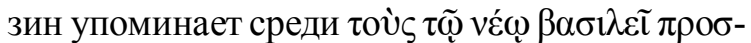

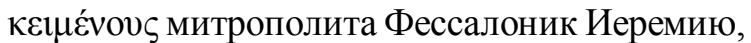
который не раз окажется втянутым в политические события в ходе войны $\left[24\right.$, p. $149^{10}, 150$, 268-269].

Итак, после событий 5 апреля Андронику II вновь стало известно о приготовлениях молодого императора и его окружения к открытому выступлению. Опасаясь мятежа, старый государь решил подвергнуть внука аресту и об этом решении сообщил патриарху Герасиму в личной беседе. Тот немедленно рассказал обо всем Андронику III [33, p. 315]. Кантакузин не называет имени доносчика и сообщает о записке ( $\beta \imath \beta \lambda i ́ o v)$, найденной у кровати молодого василевса, иносказательно, цитатой из Библии, предупреждавшей его о грозящей опасности [24, p. 89]. Присоединимся к мнению французского исследователя В. Паризо, предположившего, что Герасим в страхе быть замеченным людьми старого императора, возможно, предупредил его таким способом [38, p. 47]. Намеренно ли вмешался патриарх в обострившуюся политическую ситуацию внутри империи или неосознанно, руководствуясь лишь симпатией к молодому василевсу, сказать сложно. Так или иначе, очевидны последствия этого шага: Андроник III ускорил подготовку к мятежу и в ночь на 20 апреля бежал из столицы, тем самым начав затяжную гражданскую войну.

За день до бегства Андроника (то есть 19 апреля) Герасим скончался [3, с. 282; 24, 


\section{ВИЗАНТИЙСКАЯ ПРАВЯЩАЯ ЭЛИТА ПРИ ПАЛЕОЛОГАХ}

p. 94; 33, p. 319] ${ }^{11}$. С его смертью в Византии начался двухлетний период без патриарха. Полагаем, причиной этому послужил не только факт ведения активных боевых действий внутри государства, но и измена Герасима, о которой, вероятно, практически сразу же стало известно Андронику II (об этом косвенно свидетельствует тот факт, что о доносе патриарха знает придворный историк Григора). На следующий день, собрав прилучившихся архиереев, Андроник «приказал им подвергнуть

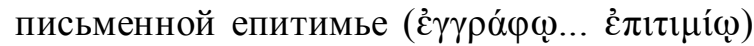
(согласно Ж. Даррузе, «отлучению» [29, р. 74, no. 2103]) и внука, как отступника, и ушедших вместе с ним». В отсутствие патриарха синод ${ }^{12}$ не оказал сопротивления решению императора; даже Григора отмечает, с какой легкостью было осуществлено это предприятие [33, p. 319]. Вооружившись церковной анафемой, Андроник, тем не менее, не смог противостоять внуку в военном отношении и подписал мир в Регии в июне 1321 года [24, p. 109-119]. Молодой император и его сторонники добились также и отмены церковного отлучения: «тотчас же собрав во дворце находившихся в Константинополе архиереев, он $<$ Андроник II > совершил клятвы и уничтожил произнесенное прежде в отношении молодого василевса и его приверженцев отлучение (использована более конкретная лексема

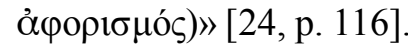

Рукоположение нового владыки состоялось лишь 30 ноября 1323 года [3, с. 282]. На этот раз император выбрал в качестве патриарха афонского монаха-исихаста Исайю (13231334). По словам Григоры, тот, как и Герасим, уже достиг преклонного возраста, совершенно не владел грамотой, и по этим причинам, считает историк, на него и пал выбор старого василевса. Новый патриарх, впрочем, оказался далеко не таким простым, каким он предстал в описании Григоры. В скором времени Исайя приобрел определенное влияние на императора. Так, по его протекции был освобожден из заключения опальный полководец Алексей Дука Филантропин (1324), почти тридцать лет назад осужденный и ослепленный за попытку захвата власти [33, p. 360]. 2 февраля 1325 г. новый патриарх короновал молодого Андроника в храме Святой Софии в качестве соправителя [3, с. 282; 24, p. 196; 33, p. 373].
Вскоре политическая ситуация в империи значительно ухудшилась. Осенью 1327 г. мятежные части во главе с Андроником III двинулись к столице и расположились лагерем близ Регия. Оттуда молодой василевс отослал письма, адресованные его деду Андронику II и патриарху Исайе, в Константинополь, требуя, чтобы его либо пропустили в город, либо отправили к нему представителей церкви и синклита для разрешения сложившегося положения. Старый император не отважился открыть ворота перед мятежниками и, снарядив посольство в составе членов синклита и архиереев, отослал его к своему внуку [24, p. 219-226; 33, p. 397]. Тот, ласково приняв послов, в итоге совершенно расположил их к себе. Добившись своего, он потребовал от деда большой денежной суммы на содержание своего войска, чтобы, таким образом, заглушить разногласия в императорской семье и вновь прийти к миру в государстве [33, p. 402]. Отпустив послов, Андроник III стал ждать ответа от старого императора.

По возвращении посольства в столицу Андроник II отказался выслушивать доводы его участников, чем лишь усугубил ситуацию. Вместо этого он потребовал от Исайи более не допускать, «чтобы во время священнодействий и в храме Святой Софии, и в других церквях упоминалось имя его внука» [24, p. 217]. Это решение послужило началом конфронтации императора и патриарха и вновь на некоторое время раскололо столичный клир, и поэтому следует более подробно остановиться на упомянутом эпизоде.

Согласно Кантакузину, Исайя вопрошал у императора о причинах исключения имени молодого василевса из литургии. «Ведь если бы он впал в какое-нибудь чужеземное учение церкви, даже тогда не следовало бы изгонять его из церквей прежде всяческого увещевания и попытки <вернуть его обратно>»

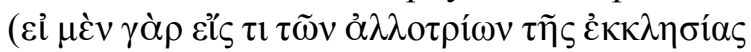

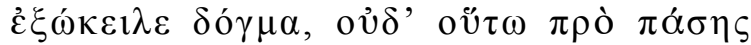

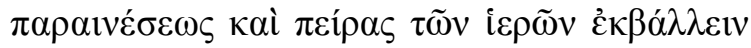
$\chi \rho \grave{)}$. Помимо этого, Исайя сообщил императору о своем намерении отправиться к Регию и попытаться исправить ситуацию и просил василевса предоставить ему такую возможность. Если бы молодой Андроник «сложил с себя... неправые представления, приветство- 
вал бы истину и познал целебность догм», тогда, по мысли Исайи, можно было бы избежать смуты внутри государства. Напротив, если бы патриарх не смог переубедить императора-внука, он обязывался не только отменить упоминание его имени в столичных церквях, но и отлучить того от церковного общения. В ответ Андроник II заметил, что «обвиняет своего внука не в порче веры, а в нарушении клятв и договоров», поэтому дело, по мысли василевса, невозможно было уладить одними лишь увещеваниями патриарха. Как и прежде, старый император вновь обратил церковь против внука, однако на этот раз столкнулся с сопротивлением церковного владыки, который отказался выполнять его приказание. Таким образом, согласно Кантакузину, имя Андроника III перестало упоминаться в дворцовых церквях, тогда как в Святой Софии и прочих церквях Константинополя упоминались имена обоих императоров [24, p. 218-219].

Тем временем император не допускал к себе вернувшихся делегатов уже на протяжении шести дней с момента их возвращения в столицу, что беспокоило патриарха. Он сообщил василевсу о необходимости принять вернувшихся архиереев, на что получил соответствующие обещания, которые не были выполнены. По истечении следующих шести дней Исайя вновь обратился к императору с теми же самыми увещеваниями. В этот раз он получил достаточно резкий ответ от Андроника, гласивший, что никому не дозволено указывать, «как вести дела его дома» (о̋

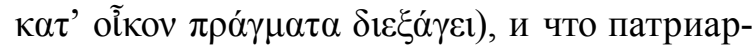
ху следует иметь заботу над церковными делами и не вмешиваться в дела государствен-

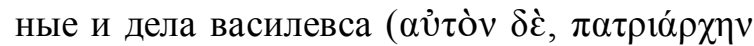

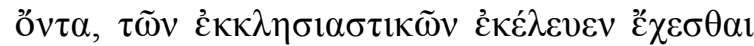

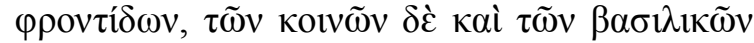

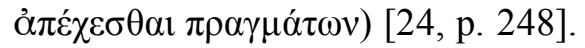

Такая твердая линия поведения Андроника II по отношению к духовному владыке отмечена лишь Кантакузином; в сочинении же Григоры император, как и прежде, поначалу оказывается вне церковного конфликта. В рамках изложения первой книги своего труда Кантакузин в принципе имеет своей целью выставить старого василевса деспотичным правителем, который в порыве гнева зачастую поступает круто и непоследовательно. Если следовать этому автору, Андроник, ранее осуществляя подобные меры в согласии с церковью (к примеру, когда он отлучил своего внука и его сообщников от церкви в начале войны), столкнувшись с несогласием ее главы, не принял мнение патриарха и продолжил гнуть свою линию. Старый император четко ограничил сферу влияния владыки церковными вопросами, тогда как сам постоянно вмешивался в сферу, которую американский исследователь Д. Джианакоплос называет внешним аспектом церкви, или иерковной политией (church polity). Она заключала в себе право назначать/отстранять патриарха (впрочем, не самостоятельно, а лишь с одобрения синода), учреждать/изменять границы церковных диоцезов, участвовать в решении дисциплинарных вопросов, касающихся духовенства, и т. д. [20, p. 387, 388-390]. К ней также можно отнести и меры, которые предпринял Андроник II, сначала отлучив своего внука и прочих мятежных лидеров от церковного общения, а затем запретив упоминать имя молодого василевса в церквях Константинополя. Следует подчеркнуть, что в выражениях Кантакузина император вообще называет последнюю меру «делом его дома», не относя ее к церковной сфере.

Практика вмешательства светской власти в дела церкви была обычной для Византии и имела как приемлемые, так и достойные осуждения виды [17, p. 302], а в недавнее патриаршество Афанасия она вновь получила идеологическое обоснование со стороны самого главы церкви $[1$, с. 55]. Впрочем, Андроник II, обладая мягким характером, не воспрещал патриархам посредством советов, наставлений, рекомендаций или предложений вмешиваться в процесс управления государством, что прекрасно иллюстрирует пример Афанасия I [1, с. 55 слл.; 27, p. 105 ff.]. Даже во время «суда», устроенного Иоанном ХІІ над Андроником II, в ходе которого патриарх изъявил императору свое недовольство рядом принятых им мер, василевсу удалось разрядить обстановку и достичь согласия с владыкой [9, c. 361-365]. Тем более непонятной кажется реакция старого императора на возражения Исайи, что заставляет сомневаться в искренности слов Кантакузина. 
Вернемся к тексту. В ответ на заявление Андроника Исайя возразил, что никогда не перестанет давать советы императору «ни добровольно, ни против воли, охваченный страхом ( $\delta \varepsilon \dot{\varepsilon} 1 \lambda \eta \varphi \theta \varepsilon \dot{\varepsilon} \varsigma) »$. Патриарх объяснял это тем, что в этом он видит едва ли не свою прямую обязанность. «Если бы я по-другому рассматривал то, что приличествует патриарху, я бы уступил престол другому, отдавшему предпочтение проводить жизнь таким образом», - утверждал Исайя. «Поскольку же я не только сделался Божией Милостью блюстителем истинных учений церкви, но и вынужден становиться в защиту и бороться за тех, против кого совершилось беззаконие, я не перестану воинственно выступать против тех, кто стремится совершать беззакония и притеснять, имеют ли они ничтожное происхождение или прославленное и достигли самой вершины успеха. И против этих я буду бороться тем более, что их преступления более значительны и причиняют вред большему числу людей» [24, p. 248-249]. Таким образом, Исайя выставил старого императора виновником сложившейся ситуации, а его внука - жертвой беззакония со стороны деда.

Далее патриарх изложил традиционную [17, p. 238] сентенцию, заключавшуюся в сравнении государства и двух ветвей власти с телом и душой, где душа - это духовная, а тело - светская власть, на примере которой он попытался доказать невозможность невмешательства души в деятельность тела. Наконец, уверенный, по его словам, в правоте молодого василевса, он умолял старого Андроника поступить благоразумно и, не доверяя более «людям, лишившимся рассудка»

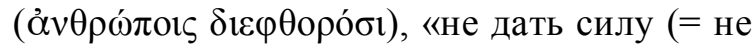
придать вес, значение) лжи взять верх над

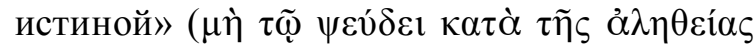

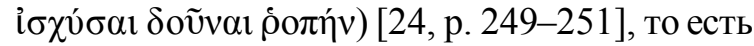
достигнуть мира с внуком.

Демагогия, отраженная на страницах труда Кантакузина, отсутствует в сочинении Григоры. Умалчивая подробные обстоятельства конфликта между императором и патриархом, приводимые Кантакузином, Григора сообщает о заговоре против Андроника II, организованном Исайей и примкнувшими к нему архиереями. Выслушав речь василевса, в которой тот предложил синоду запретить поминовение имени его внука в литургии, Исайя и некоторые архиереи, собравшись в патриарших покоях, «составили заговор и союз

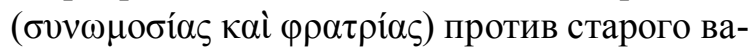
силевса». Вскоре он проник «в народ и знат-

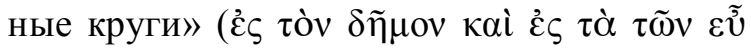

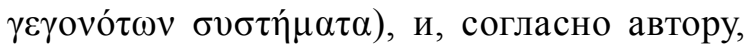
многие примкнули к нему. Заговорщикам даже удалось вывести часть столичного населения на улицы: на третий день патриарх, собрав

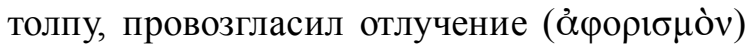
каждому, кто решился бы опускать имя молодого императора в священнодействиях [33, p. 405-406].

Такое положение дел грозило очередным церковным расколом, однако этого не случилось, поскольку синод в последний момент поддержал старого императора. Архиереев, принявших сторону Андроника II, оказалось больше, чем тех, кто последовал за Исайей, и в конечном итоге старый император, опасаясь дальнейших смут, лишил Исайю патриаршества и заключил его в Манганский монастырь, который тот не имел права покидать [33, p. 406-407]. Факт помещения Исайи в монастырь отмечен и Кантакузином [24, р. 252], правда, обстоятельства, которые привели Андроника II к этому решению, представлены иначе: настойчивые просьбы патриарха уладить дело миром привели к его опале. Лишь после взятия Константинополя мятежной армией патриарх был с большими почестями освобожден Андроником III и восстановлен в сане [24, p. 305; 33, p. 424-425]; этот факт, наряду с другими деталями освобождения Исайи, косвенно указывает на реальные мотивы его антиправительственной деятельности. Исайя вернулся в патриарший дворец, окруженный танцорами и танцовщицами на украшенной пурпуром царской колеснице, и по возвращению начал репрессивную деятельность в отношении священнослужителей, которые выступили против него осенью 1327 г., «и одним он приказал воздерживаться от священнослужения в течение назначенных лет, а другим - до смерти. Впрочем, были и такие, на которых он наложил более умеренную епитимью. Говоря же проще, никого из сторонников старого василевса он не оставил

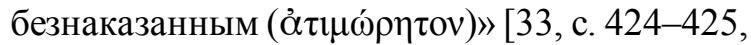
429]. Стоит вновь обратить внимание на то, 
что крутые меры Исайи, последовавшие за его восстановлением на патриаршем престоле, засвидетельствованы лишь Никифором Григорой, тогда как в сочинении Кантакузина подобные сведения отсутствуют.

Итак, следует отметить достаточно высокую роль церкви в политических событиях в Византии периода гражданской войны 13211328 годов. Оба василевса стремились заручиться поддержкой церковных иерархов, пытаясь найти в них опору в условиях политического кризиса. В этом отношении Андроник II в целом добился успеха, стяжав симпатии синода, который в последний момент поддержал императора в борьбе с мятежным патриархом Исайей. Так или иначе, кризис власти привел к перемене в отношениях между владыками и Андроником II. Герасим I и Исайя выступали на стороне его внука, и если первый изменил императору по не вполне выясненным мотивам, то Исайя действовал, прежде всего оценивая политическую конъюнктуру и рассчитывая на дальнейшую перспективу, то есть руководствуясь личными побуждениями. Этот факт весьма показателен в контексте осмысления участия церкви в событиях гражданской войны и выяснения ее роли в ней.

\section{ПРИМЕЧАНИЯ}

1 Отдельно следует упомянугь статью М.А. Поляковской, в которой автор, занятая изучением проблемы отношений государства и церкви в более поздний период византийской истории, также уделила внимание вопросу определения позиции столичного духовенства по отношению к враждующим сторонам [6, c. 62-63].

$[18$, p. 83$]$.

2 Относительно даты отлучения Михаила:

${ }^{3}$ Кроме того, Лионская уния стала поводом к проведению поместного антиуниатского собора 1277 г. в Фессалии, на котором были подвергнуты церковному отлучению все причастные к ней [23, p. 321-322].

${ }^{4}$ Относительно даты: [19, p. 43].

5 «Они (противники Афанасия. - П. Л.) похитили подножие от его патриаршего трона; внизу него они написали Божественный образ Христа Спасителя, а с обеих его сторон - василевса Андроника, несущего во рту уздечку, и патриарха Афанасия, тянущего его <за узду>, как какой-нибудь ко-

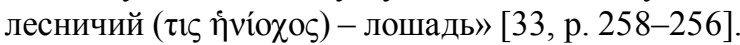

${ }^{6}$ Датировка события: [28, p. 149].
${ }^{7}$ Помимо оригинального текста [33], к написанию статьи также привлекался его перевод на русский язык [4].

8 Помимо оригинального текста [24], мы также использовали его перевод на немецкий язык [25].

${ }^{9}$ Источники противоречат друг другу в вопросе датировки; так, в тексте сочинения Никифора Григоры в качестве даты суда над Андроником III указана шестая неделя Великого Поста (6-12 апреля). Согласно же Кантакузину, суд состоялся 'А $\rho \imath \lambda \lambda i ́ o v$

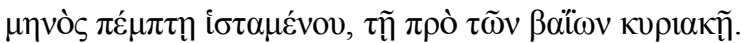
Поддержим версию Кантакузина, как более точную. Часть специалистов придерживается этой же точки зрения: [11, с. 96; 16, S. 19; 38, p. 42 ff.].

10 Отмечен как «проэдр» ( $\pi \rho \varepsilon_{\varepsilon} \delta \rho \varsigma_{)}$церкви в Фессалониках.

11 Показания источников не совпадают. Согласно хронике, впервые изданной Б.П. Горяновым, патриарх умер 20 апреля. Кантакузин отмечает, что патриарх умер в туже ночь, что и бежал молодой Андроник, то есть в ночь на 19 апреля, так как автор отмечает факт бегства императора именно этой датой. Принимаем датировку Григоры, как наиболее последовательную.

12 «Немедленно созвав находившихся в Виза́-

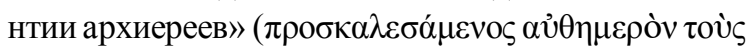

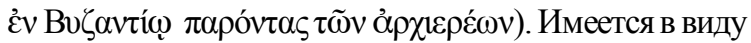

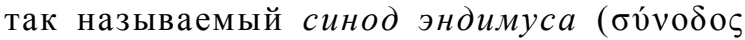
$\dot{\varepsilon} v \delta \eta \mu о \tilde{\sigma} \sigma \alpha)$, то есть собор, постоянно действовавший при патриархе и состоявший из архиереев, приезжавших в Константинополь по делам или живших в городе или близ него. См. подробнее: [37, p. 697].

\section{СПИСОК ЛИТЕРАТУРЫ}

1. Барабанов, Н. Д. Отношения церкви и государства в Византии на рубеже XIII-XIV вв. (патриapx Афанасий I и Андроник II Палеолог) / Н. Д. Барабанов // Античная древность и средние века. - 1983. Вып. 20 : Развитие феодализма в Центральной и ЮгоВосточной Европе. - С. 52-63.

2. Барабанов, Н. Д. О характере выступления Иоанна Дримия в начале XIV в. / Н. Д. Барабанов // Античная древность и средние века. 1980. - Вып. 17. - С. 53-60.

3. Горянов, Б. Т. Неизданный анонимный византийский хронограф XIV века / Б. Т. Горянов // Византийский временник. - 1949. - Т. 2. - С. 276-293.

4. Никифор Григора. История ромеев. В 3 т. Т. 1. Кн. I-ХI / Никифор Григора ; пер. Р. В. Яшунского ; вступ. ст. Л. Герд. - СПб. : Свое изд-во, 2013. 438, [42] c.

5. Пападакис, А. Христианский восток и возвышение папства : Церковь в 1071-1453 гг. / А. Пападакис, прот. И. Мейендорф ; пер. с англ. А. В. Ле- 
витского, У. С. Рахновской, А. А. Чеха. - М. : Изд-во ПСТГУ, 2010. -630 с.

6. Поляковская, М. А. Участие византийских монастырей в политической жизни империи середины XIV в. / М. А. Поляковская // Античная древность и средние века. - 1969. - Вып. 6. - С. 55-78.

7. Пржегорлинский, А., свящ. Византийская церковь на рубеже XIII-XIV вв. Деятельность и наследие св. Феолипта, митрополита Филадельфийского / свящ. Александр Пржегорлинский ; науч. ред. Н. Д. Барабанов. - СПб. : Алетейя, 2011. - 240 с.

8. Соколов, И. И. О византинизме в церковноисторическом отношении. Избрание патриархов в Византии с середины IX до начала XV в. (8431453 гг.). Вселенские судьи в Византии / И. И. Соколов ; вступ. ст. Г. Е. Лебедевой. - СПб. : Изд-во Олега Абышко, 2003. - 272 с.

9. Троицкий, И. Е. Арсений, патриарх Никейский и Константинопольский, и арсениты (к истории восточной церкви в ХІІІ веке) / И. Е. Троицкий. -СПб. : Тип. Департамента уделов, 1873. -534 с.

10. Успенский, Ф. И. История Византийской империи. Т. 3 : Отдел VI. Комнины ; Отдел VII. Расчленение империи ; Отдел VIII. Ласкари и Палеологи. Восточный вопрос / Ф. И. Успенский ; сост. Л. В. Литвинова. - М. : Мысль, 1997. - 829, [2] с.

11. Флоринский, Т. Д. Андроник Младший и Иоанн Кантакузин : Очерк истории Византии во второй четверти XIV в. (1328-1355 гг.) / Т. Д. Флоринский // Журнал Министерства народного просвещения. - 1879. - Ч. CCIV. - С. 87-251.

12. Bartusis, M. C. The late Byzantine army: Arms and society, 1204-1453 / M. C. Bartusis. - Philadelphia : University of Pennsylvania Press, 1997. - xvii, 438 p.

13. Beck, H.-G. Geschichte der Orthodoxen Kirche im Byzantinischen Reich / H.-G. Beck. - Göttingen : Vandenhoeck \& Ruprecht, 1980. - 268, [6] S.

14. Bompaire, J. Le querelle de deux Andronic et le mont Athos en 1322 / J. Bompaire, L. Mavromatis // Revue des études byzantines. - 1974. - T. 32. P. 187-198.

15. Boojamra, J. L. Church reform in the late Byzantine empire : A study for the patriarchate of Athanasios of Constantinople / J. L. Boojamra. -

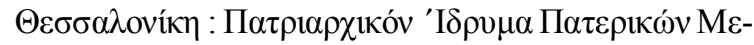
$\lambda \varepsilon \tau \omega \dot{~ v, ~ 1982 . ~}-239$ p.

16. Bosch, U. V. Kaiser Andronikos III. Palaiologos : Versuch einer Darstellung der byzantinischen Geschichte in den Jahren 1321-1341 / U. V. Bosch. - Amsterdam : Verl. AdolfM. Hakkert, 1965.-216, [22] S.

17. Dagron, G. Empereur et prêtre : Étude sur le "césaropapisme" byzantin / G. Dagron. - Paris : Gallimard, 1996. - 435, [13]p.

18. Failler, A. Chronologie et composition dans l'Histoire de Georges Pachymère / A. Failler // Revue des études byzantines. - 1980. - T. 38. - P. 5-103.
19. Failler, A. Chronologie et composition dans l'Histoire de Georges Pachymérès (livres VII-XII) / A. Failler // Revue des études byzantines. - 1990. - T. 48. - P. 5-87.

20. Geanakoplos, D. J. Church and state in the Byzantine empire : A reconsideration of the problem of caesaropapism / D. J. Geanakoplos // Church history. 1965. - Vol. 34, № 4. - P. 381-403.

21. Georges Pachymérès. Relations historiques / Georges Pachymérès ; éd., trad. fr. et notes par A. Failler. - Paris : Institut Français d'Études Byzantines, 1999. - xxiv, $305 \mathrm{p}$.

22. Gill, J. Emperor Andronicus II and patriarch Athanasius I / J. Gill // BYZANTINA. - 1970. - T. 2. P. 13-19.

23. Grumel, V. En Orient après le IIe Concile de Lyon. Brèves notes d'histoire et de chronologie / V. Grumel //Échos d'Orient. - 1925. - Vol. 24. - P. 321-325.

24. Ioannis Cantacuzeni eximperatoris Historiarum libri IV. Vol. I/ Ioannes Cantacuzenus; ed. L. Schopen. - Bonna [Bonn] : Impensis Ed. Weberi, 1828. - xxxvi, $560 \mathrm{p}$.

25. Johannes Kantakuzenos. Geschichte. 1. T. (B. I) / Iohannes Kantakuzenos ; übers. und erl. von Georgios Fatouros und Tilman Krischer. Stuttgart : Anton Hiersemann, 1982. - viii, 334, [2] S.

26. Laiou, A. E. Constantinople and the Latins : The foreign policy of Andronicus II, 1282-1328/A. E. Laiou. Cambridge (Mass.) : Harvard University Press, 1972. xii, 390 p.

27. Laiou, A. E. The provisioning of Constantinople during the winter of 1306-1307 / A. E. Laiou // Byzantion. 1967. - T. XXXVII. - P. 91-113.

28. Laurent, V. La chronologie des patriarches de Constantinople de la première moitié du $\mathrm{XIV}^{\mathrm{e}}$ siècle (1294-1350) / V. Laurent // Revue des études byzantines. -1949 . - T. $7 .-$ P. $145-155$.

29. Les regestes des actes du patriarcat de Constantinople. Vol. I : Les actes des patriarches, Fasc. V : Les regestes de 1310 à 1376 / Éd. par J. Darrouzès. - Paris : Institut Français d'Études Byzantines, 1977. - xx, 601, [3] p.

30. Lettre d'Andronic II Paléologue / Andronic II Paléologue // Actes de Vatopédi. I : Des origines à 1329 / Éd. diplomatique par J. Bompaire, J. Lefort, V. Kravari, C. Giros. - Paris : P. Lethielleux, 2001.P. 308-311.

31. Lettre d'Andronic II Paléologue / Andronic II Paléologue // Actes de Vatopédi. I : Des origines à 1329 / Éd. diplomatique par J. Bompaire, J. Lefort, V. Kravari, C. Giros. - Paris : P. Lethielleux, 2001.P. 311-313.

32. Lettre d'Andronic II Paléologue / Andronic II Paléologue // Actes de Vatopédi. I : Des origines à 1329 / Éd. diplomatique par J. Bompaire, J. Lefort, V. Kravari, C. Giros. - Paris : P. Lethielleux, 2001.P. 313-315. 
33. Nicephori Gregoræ Byzantina Historia. Vol. I / Nicephorus Gregoras; ed. L. Schopen. - Bonna [Bonn] : Impensis Ed. Weberi, 1829. - 568 p.

34. Nicol, D.M. The last centuries of Byzantium, 1261-1453 / Donald M. Nicol. - 2nd ed. - Cambridge : Cambridge University Press, 1993. - xx, 463 p.

35. Nicol, D.M. The reluctant emperor : A biography of John Cantacuzene, Byzantine emperor and monk, c. 1295-1383 / D. M. Nicol. - N. Y. : Cambridge University Press, 1996. - 203, [21] p.

36. Ostrogorsky, G. Geschichte des Byzantinischen Staates / G. Ostrogorsky. - 3., durchgearb. Aufl. München :C.H. Beck'scheVerl.-Buchh., 1963.-xxxi, 514S.

37. Papadakis, A. Endemousa synodos /A. Papadakis // Oxford Dictionary of Byzantium. Vol. I / ed. A. P. Kazhdan [et al.]. - N. Y. ; Oxford : Oxford University Press, 1991. - P. 697.

38. Parisot, V. Cantacuzène homme d'état et historien ou examen critique comparatif des Mémoires de l'empereur Jean Cantacuzène et des sources contemporaines, et notamment des 30 livres dont 14 inédits de l'Histoire de Nicéph. Grégoras qui controlent les Mémoires de Cantacuzène / V. Parisot. Paris : Joubert, Libraire, 1845. - 336 p.

39. Talbot, A.-M. M. The patriarch Athanasius (1289-1293; 1303-1309) and theChurch/A.-M. M. Talbot // Dumbarton Oaks Papers. - 1973. - Vol. 27. - P. 11-28.

\section{REFERENCES}

1. Barabanov N.D. Otnosheniya tserkvi i gosudarstva v Vizantii na rubezhe XIII-XIV vv. (patriarkh AfanasiyI i Andronik II Paleolog) [Church-State Relations in Byzantium at the Turn of the 13th-14th Centuries (the Patriarch Athanasios I and Andronikos II Palaiologos)]. Antichnaya drevnost i srednie veka, 1983, iss. 20: The Development of Feudalism in the Central and SouthEastern Europe, pp. 52-63.

2. Barabanov N.D. O kharaktere vystupleniya Ioanna Drimiya v nachale XIV veka [On the Nature of the John Drimys' Revolt in the Early 14th Century]. Antichnaya drevnost $i$ srednie veka, 1980, vol. 17, pp. 53-60.

3. Goryanov B.T. Neizdannyy anonimnyy vizantiyskiy khronograf XIV veka [An Unpublished ByzantineAnonymous Chronograph of the 15th Century]. Vizantiyskiy vremennik, 1949, vol. 2, pp. 276-293.

4. Yashunskiy R.V., Gerd L., eds. Nikifor Grigora. Istoriya romeev. V3 t. T. 1. Knigi I-XI[Nicephorus Gregoras. The History of the Romans. In 3 vols. Vol. I. Books I-XI]. Saint Petersburg, Svoe izd-vo, 2013.438, [42]p.

5. Papadakis A. Khristianskiy vostok $i$ vozvyshenie papstva: Tserkov v 1071-1453 gg. [The Christian East and the Rise of the Papacy: the Church in 1071-1453 AD]. Moscow, Izd-vo PSTGU, 2010. 630 p.
6. Polyakovskaya M.A. Uchastie vizantiyskikh monastyrey v politicheskoy zhizni imperii serediny XIV v. [Participation of Byzantine Monasteries in Political Life of the Empire in the mid-14th Century]. Antichnaya drevnost i srednie veka, 1969, vol. 6, pp. 55-78.

7. Przhegorlinskiy A., svyashch. Vizantiyskaya tserkov na rubezhe XIII-XIVvv. Deyatelnost i nasledie sv. Feolipta, mitropolita Filadelfiyskogo [The Byzantine Church at the Turn of the 13th-14th Centuries. Activities and Legacy of St. Theoleptos, Metropolitan of Philadelphia]. Saint Petersburg, Aleteya Publ., 2011. 240 p.

8. Sokolov I.I. O vizantinizme $v$ tserkovnoistoricheskom otnoshenii. Izbranie patriarkhov $v$ Vizantii s serediny IX do nachala XV veka (8431453 gg.). Vselenskie sudyi $v$ Vizantii [On the Byzantinism in Church-Historical Respect. The Patriarchs' Election in Byzantium from the mid - 9th to the early 15th Centuries (843-1453)]. Saint Petersburg, Izd-vo Olega Abyshko, 2003. 272 p.

9. Troitskiy I.E. Arseniy, patriarkh Nikeyskiy $i$ Konstantinopolskiy, $i$ arsenity ( $k$ istorii vostochnoy tserkvi v XIII veke) [Arsenius, Patriarch of Nicaea and Constantinople, and the Arsenites (To the Eastern Church History During the 13th Century)]. Saint Petersburg, Tip. Departamenta udelov, 1873. 534 p.

10. Uspenskiy F.I. Istoriya Vizantiyskoy imperii. T. 3. Otdel VI. Komniny; Otdel VII. Raschlenenie imperii; Otdel VIII. Laskari i Paleologi. Vostochnyy vopros [The History of the Byzantine Empire. Vol. 3. Section 6. The Komnenoi. Section 7. The Division of the Empire. Section 8. The Lascarids and the Palaiologoi. The Eastern Issue]. Moscow, Mysl Publ., 1997. 829, [2] p.

11. Florinskiy T.D. Andronik Mladshiy i Ioann Kantakuzin: Ocherk istorii Vizantii vo vtoroy chetverti XIV veka (1328-1355 gg.) [Andronikos The Younger and John Kantakouzenos: An Essay of the Byzantine History in the Second Quarter of the 14th Century (1328-1355)]. Zhurnal Ministerstva narodnoho prosveshcheniya, 1879, vol. 204, pp. 87-251.

12. Bartusis M.C. The Late Byzantine Army: Arms and Society, 1204-1453. Philadelphia, University of Pennsylvania Press, 1997. xvii, 438 p.

13. Beck H.-G. Geschichte der Orthodoxen Kirche im Byzantinischen Reich [History of the Orthodox Church in the Byzantine Empire]. Göttingen, Vandenhoeck \& Ruprecht, 1980. 268, [6] p.

14. Bompaire J., Mavromatis L. Le querelle de deux Andronic et le mont Athos en 1322. Revue des études byzantines, 1974, vol. 32, pp. 187-198.

15. Boojamra J.L. Church Reform in the Late Byzantine Empire: A Study for the Patriarchate of Athanasios of Constantinople. Thessaloniki, Patriarchikon Hidryma Paterikôn Meletôn Publ., 1982. $239 \mathrm{p}$. 


\section{ВИЗАНТИЙСКАЯ ПРАВЯЩАЯ ЭЛИТА ПРИ ПАЛЕОЛОГАХ}

16. Bosch U.V. Kaiser Andronikos III. Palaiologos: Versuch einer Darstellung der byzantinischen Geschichte in den Jahren 13211341. Amsterdam, Verl. Adolf M. Hakkert, 1965. 216, [22] p.

17. Dagron G. Empereur et prêtre: Étude sur le “césaropapisme” byzantin. Paris, Gallimard, 1996.435, [13] p.

18. Failler A. Chronologie et composition dans l'Histoire de Georges Pachymère. Revue des études byzantines, 1980, vol. 38, pp. 5-103.

19. Failler A. Chronologie et composition dans l'Histoire de Georges Pachymérès (livres VII-XII). Revue des études byzantines, 1990, vol. 48, pp. 5-87.

20. Geanakoplos D.J. Church and State in the Byzantine Empire: A Reconsideration of the Problem of Caesaropapism. Church history, 1965, vol. 34, no. 4, pp. 381-403.

21. Failler A., ed. Georges Pachymérès. Relations historiques. Paris, Institut Français d'études Byzantines, 1999. xxiv, 305 p.

22. Gill J. Emperor Andronicus II and Patriarch Athanasius I. BYZANTINA, 1970, vol. 2, pp. 13-19.

23. Grumel V. En Orient après le IIe Concile de Lyon. Brèves notes d'histoire et de chronologie. Échos d'Orient, 1925, vol. 24, pp. 321-325.

24. Schopen L., ed. Ioannis Cantacuzeni eximperatoris Historiarum libri IV. Vol. I. Bonna [Bonn], Impensis Ed. Weberi, 1828. xxxvi, 560 p.

25. Fatouros G., Hiersemann A., eds. Johannes Kantakuzenos. Geschichte. 1. T. (B.I). Stuttgart, Anton Hiersemann, 1982. viii, 334, [2] p.

26. Laiou A.E. Constantinople and the Latins: The Foreign Policy of Andronicus II, 1282-1328. Cambridge (Mass.), Harvard University Press, 1972. xii, 390 p.

27. Laiou A.E. The Provisioning of Constantinople During the Winter of 1306-1307. Byzantion, 1967, vol. 37, pp. 91-113.

28. Laurent V. La chronologie des patriarches de Constantinople de la première moitiédu $\mathrm{XIV}^{\mathrm{e}}$ siècle (1294-1350). Revue des études byzantines, 1949, vol. 7, pp. 145-155.
29. Darrouzès J., ed. Les regestes des actes du patriarcat de Constantinople. Vol. I: Les actes des patriarches, Fasc. V: Les regestes de 1310 à 1376. Paris, Institut Français d'études Byzantines, 1977. xx, 601, [3] p.

30. Bompaire J., Lefort J., Kravari V., Giros C., eds. Lettre d'Andronic II Paléologue. Actes de Vatopédi. I: Des origines à 1329. Paris, P. Lethielleux, 2001, pp. 308-311.

31. Bompaire J., Lefort J., Kravari V., Giros C., eds. Lettre d'Andronic II Paléologue. Actes de Vatopédi. I: Des origines à 1329. Paris, P. Lethielleux, 2001, pp. 311-313.

32. Bompaire J., Lefort J., Kravari V., Giros C., eds. Lettre d'Andronic II Paléologue. Actes de Vatopédi. I: Des origines à 1329. Paris, P. Lethielleux, 2001, pp. 313-315.

33. Schopen L., ed. Nicephori Gregorce Byzantina Historia. Vol. I. Bonna [Bonn], Impensis Ed. Weberi, 1829. 568 p.

34. Nicol D.M. The Last Centuries of Byzantium, 1261-1453. Cambridge, Cambridge University Press, 1993. xx, $463 \mathrm{p}$.

35. Nicol D.M. The Reluctant Emperor: A Biography of John Cantacuzene, Byzantine Emperor and Monk, c. 1295-1383. New York, Cambridge University Press, 1996. 203, [21] p.

36. Ostrogorsky G. Geschichte des Byzantinischen Staates. München, C.H. Becksche Verl.-Buchh., 1963. xxxi, 514p.

37. Papadakis A. Endemousa synodos. Kazhdan A.P. et al., eds. Oxford Dictionary of Byzantium. Vol. I. New York; Oxford, Oxford University Press, 1991, p. 697.

38. Parisot V. Cantacuzène homme d'état et historien ou examen critique comparatif des Mémoires de l'empereur Jean Cantacuzène et des sources contemporaines, et notamment des 30 livres dont 14 inédits de l'Histoire de Nicéph. Grégoras qui controlent les Mémoires de Cantacuzène. Paris, Joubert, Libraire, $1845.336 \mathrm{p}$.

39. Talbot A.-M.M. The Patriarch Athanasius (1289-1293; 1303-1309) and the Church. Dumbarton Oaks Papers, 1973, vol. 27, pp. 11-28.

\section{Information About the Author}

Pavel I. Lysikov, Postgraduate Student, Department of Archaeology, World History and Tourism, Volgograd State University, Prosp. Universitetsky, 100, 400062 Volgograd, Russian Federation, blademaster18@mail.ru.

\section{Информация об авторе}

Павел Иванович Лысиков, аспирант кафедры археологии, зарубежной истории и туризма, Волгоградский государственный университет, просп. Университетский, 100, 400062 г. Волгоград, Российская Федерация, blademaster18@mail.ru. 